\title{
ATTITUDE TOWARDS PHYSICAL ACTIVITY IN FUTURE PHYSICIANS FROM GERMANY AND ITALY. A PRELIMINARY REPORT
}

\section{PODEJŚCIE DO AKTYWNOŚCI FIZYCZNEJ WŚRÓD PRZYSZŁYCH NIEMIECKICH I WŁOSKICH LEKARZY. DONIESIENIE WSTĘPNE}

\author{
Krystyna Zeńczak-Praga ${ }^{1(C, D, E, F)}$, Joanna Pluto-Prondzinska ${ }^{1(B, C)}$, \\ Małgorzata Zgorzalewicz-Stachowiak ${ }^{1(A)}$
}

${ }^{1}$ Department of Health Prophylaxis, Laboratory of Medical Electrodiagnostics, Poznan University of Medical Sciences, Poznan, Poland

Authors' contribution Wkład autorów: A. Study design/planning zaplanowanie badań B. Data collection/entry zebranie danych C. Data analysis/statistics dane - analiza i statystyki D. Data interpretation interpretacja danych E. Preparation of manuscript przygotowanie artykułu F. Literature analysis/search wyszukiwanie i analiza literatury G. Funds collection zebranie funduszy
Tables: 1

Figures: 3

References: 26

Submitted: 2016 Nov 21

Accepted: 2017 Apr 05

\section{Summary}

Background. By leading a healthy lifestyle, medical students exert a positive influence on themselves and their future patients. The aim of the study was to compare the attitudes towards physical activity in future German and Italian physicians.

Material and methods. The study involved 100 Italian and 100 German students aged from 19 to 24 years old. The research findings were drawn from Eurobarometer 72.3, which surveyed the participants on a set of questions regarding their physical activity. The chisquared test $\left(\mathrm{x}_{2}\right)$ and the Mann-Whitney U test were used for the statistical analysis.

Results. Only $4 \%$ students demonstrated high physical activity index. The Italian students usually practised sports outdoors (30\% men and $26 \%$ women) or at a fitness centre $(52 \%$ men and 30\% women), whereas the German students exercised at a fitness centre (40\% males and $64 \%$ females) or at university facilities (30\% males and $24 \%$ females). There were some statistically significant values $(\mathrm{p}=0.000398)$. The most common factors that caused physical inactivity in medical students from both nations included: lack of time, no friends to do sports with, no sense of purposefulness of exercise and aversion to competition $(p=0.000009)$. The German participants were more interested in sports than their Italian peers $(p=0.000018)$. Conclusions. Medicinal students should be more physically active because they will promote a healthy lifestyle when counselling their patients. Free access to sports grounds at the university might also encourage them to spend more their leisure time actively.

Keywords: physical activity, medical students, medical education, Germany, Italy

\section{Streszczenie}

Wprowadzenie. Studenci medycyny prowadząc zdrowy styl życia korzystnie wpływają na zdrowie swoje jak i na swoich przyszłych pacjentów. Celem badań było porównanie postaw wobec aktywności fizycznej wśród przyszłych niemieckich i włoskich lekarzy.

Materiał i metody. Do badań włączono 100 włoskich i 100 niemieckich studentów w wieku 19-24 lat. Posłużono się kwestionariuszem Eurobarometer 72.3, gdzie respondenci odpowiedzieli na kilka pytań związanych ze swoją aktywnością fizyczną. Do analizy statystycznej użyto testy chi-kwadrat oraz Manna-Whitneya.

Wyniki. Wysoką aktywność fizyczną prezentowało jedynie 4\% wszystkich ankietowanych. Przyszli włoscy lekarze zazwyczaj uprawiali sport na świeżym powietrzu (30\% mężczyzn i $26 \%$ kobiet) lub w fitness klubach (52\% mężczyzn i 30\% kobiet), podczas gdy niemieccy także w ostatnim miejscu (40\% mężczyzn i 64\% kobiet) lub na uczelni (30\% mężczyzn i 24\% kobiet). Te zależności były także istotne statystycznie $(\mathrm{p}=0,000398)$. Najczęstsze przyczyny powodujacce ograniczona aktywność fizyczną wśród studentów medycyny obu nacji to : brak czasu lub kolegów z którymi można uprawiać sport a nawet poczucia celowości wykonywania ćwiczeń oraz niechęć do współzawodnictwa $(p=0,000009)$. Niemieccy ankietowani byli również bardziej zainteresowani sportem niż ich włoscy rówieśnicy $(\mathrm{p}=0,000018)$.

Wnioski. Studenci medycyny powinni być bardziej aktywni fizyczni ponieważ są zobowiązani do promowania zdrowego stylu życia podczas udzielania porad pacjentom. Darmowy dostęp do obiektów sportowych na uczelni może ich zachęcić do częstszego aktywnego spędzania czasu wolnego.

Słowa kluczowe: aktywność fizyczna, studenci medycyny, edukacja medyczna, Niemcy, Włochy

Zeńczak-Praga K, Pluto-Prondzinska J, Zgorzalewicz-Stachowiak M. Attitude towards physical activity in future physicians from Germany and Italy. A preliminary report. Health Problems of Civilization. 2017; 11(3): 142-149. doi: 10.5114/hpc.2017.70007.

Address for correspondence / Adres korespondencyjny: Krystyna Zeńczak-Praga, Department of Health Prophylaxis, Laboratory of Medical Electrodiagnostics, Poznan University of Medical Sciences, Przybyszewskiego 49, 60-355 Poznań, Poland, e-mail: krystyna_zenczak@o2.pl, phone: +4861 8691552

Copyright: (C) 2017 Pope John Paul II State School of Higher Education in Biała Podlaska, Krystyna Zeńczak-Praga, Joanna Pluto-Prondzinska, Małgorzata Zgorzalewicz-Stachowiak. This is an Open Access journal, all articles are distributed under the terms of the Creative Commons Attribution-NonCommercial-ShareAlike 4.0 International (CC BY-NC-SA 4.0) License (http://creativecommons.org/licenses/by-nc-sa/4.0/), allowing third parties to copy and redistribute the material in any medium or format and to remix, transform, and build upon the material, provided the original work is properly cited and states its license. 


\section{Background}

Future doctors and their healthy lifestyles should positively affect their patients. It is known that physicians who are physically active more often encourage their patients to do sports. They are also more trustworthy and motivating when talking others into taking preventive measures. In addition, physical activity is also significant for medicinal students and the doctors themselves as a factor that may help them cope with large amounts of stress and anxiety related with the profession $[1,2,3]$.

On the other hand, medical courses are one of the most demanding and students may experience burnout or mental problems such as depression during the education process. Lack of sleep, insufficient amount of time, academic overload and competition can increase anxiety in medical students. After graduation, stress levels in doctors may be passed on to their patients and cause negative consequences [3-7].

While studying medicine, students learn about physical activity and its preventive role in one's life. However, in many medical schools more time is dedicated to other topics and there is not enough physical training. Generally, medical students are more active than other groups in society; yet, it has been noticed that their physical activity gradually decreases in the course of studying. Moreover, there are not many doctors who advise patients to be more physically active $[1,8]$.

Another point is one's starting a university education, which is an important step for every individual, especially when he/she studies abroad and is far from home. Students are responsible for themselves and they may transform their healthy habits into an unhealthy lifestyle $[9,10,11]$.

According to the Centre for Economic and Business Research (CEBR) and the International Sport and Culture Association (ISCA) [12], an inactive lifestyle leads not only to disorders or death but is also costly. In 2010 in Germany, $21.1 \%$ of the adults did not follow the WHO recommendations, i.e. at least 150 minutes of moderate or 75 minutes of intensive physical activity per week, or a combination of both. In Italy, the situation was even worse. As many as $33 \%$ of the adults were not sufficiently physically active. In both countries, men were more active than women, but the disproportion was much more visible in the Italian society $[12,13]$.

The socioeconomic status is an important factor as it is known that less affluent people tend to be less active. Italy is a poorer country with more social problems than Germany. It has also been proven that in countries situated in the south of Europe, such as Italy, there are more inactive and overweight children than in northern or central Europe, e.g. in Germany [12,14,15].

A lack of comparative studies on physical activity in both German and Italian medical faculty students was sufficient enough to make us conduct the following research study.

The aim of the research was to evaluate and compare the attitudes and level of physical fitness in medicine students in both countries using Eurobarometer 72.3, broken down by gender, while they were studying abroad.

\section{Material and methods}

The sample population in this research study comprised a total of 200 medicine and physiotherapy students, 19-24 years old, who studied at the Miguel Hernández University of Elche in Spain. The research was carried out with the cooperation of the Poznań University of Medical Sciences. 200 students (100 Germans and 100 Italians) participated in the survey. The number of men and women was the same. Students of other nations were not involved in the study. The vast majority of all students (77.5\%) studied medicine. Accordingly, in our study we focused on future doctors.

Students were informed about the purpose of the study and they agreed to take part in the survey. The Poznań University of Medical Sciences provided ethical approval of the study and a provision to protect participants privacy. The research method was a questionnaire and the respondents answered several questions drawn from Eurobarometer 72.3. The original questionnaire had been prepared by the European Commission and focused on sports and physical activity in the European Union with a separate analysis for each country and for persons aged 15 years and above.

According to the following survey, the students were asked how frequency they were involved in doing physical activity and where they usually exercised. There were also questioned about the factors influencing decreased physical activity. Moreover, opinions about interest in sports were gathered [16].

The students were asked to provide some basic information on their age, body weight and body height. The Body Mass Index (BMI) was also evaluated in order to check each student's weight status category. 


\section{Statistical analysis}

The results are presented as a mean \pm SD. For statistical analysis, the chi-squared test $\left(x^{2}\right)$ and the MannWhitney U test were used. The data that were statistically significant were described with a $\mathrm{p}-$ value $(\mathrm{p}<0.05)$. The Statistica 12.0 Software was used for all calculations.

\section{Results}

The age of the students participating in the study ranged from 19 to 24 years. The German males were the youngest, the mean age of $21.3 \pm 1.33$ years, whereas the Italian males were the oldest, the mean age of $22.04 \pm 1.28$ years. Both the Italian men and women had lower body weight than their German colleagues. However, the Italian students were also shorter. The Italian females were the shortest, the mean height of $164.8 \pm 2.15 \mathrm{~cm}$. The normal mean value of BMI was observed in all groups, but the Italian females presented the lowest mean value of BMI, i.e. 21.68 \pm 1.08 . There were only a few students from both countries who were overweight (3 Italian and 2 German). The rest of the respondents demonstrated normal BMI. Statistically significant differences with $p<0.05$ were noticed only in the height of the tested students from the two countries $(p=0.000009)$. There were no statistically significant differences with regard to gender. The sample description is presented in Table 1.

Table 1. Mean age, weight, height and BMI

\begin{tabular}{|c|c|c|c|c|c|}
\hline & \multicolumn{2}{|c|}{ Women } & \multicolumn{2}{c|}{ Men } & Germany \\
\hline & Italy & Germany & Italy & value \\
\hline Age (years) & $21,9 \pm 1,04$ & $21,84 \pm 1,3$ & $22,04 \pm 1,28$ & $21,34 \pm 1,33$ & NS \\
\hline Weight (kg) & $58,9 \pm 3,46$ & $65,64 \pm 3,78$ & $63,92 \pm 4,43$ & $67,96 \pm 4,76$ & $\mathrm{p}=0,000009$ \\
\hline Height (cm) & $164,8 \pm 2,15$ & $171,9 \pm 3,21$ & $168,76 \pm 2,29$ & $174,7 \pm 4,38$ & NS \\
\hline BMI & $21,68 \pm 1,08$ & $22,22 \pm 1,2$ & $22,44 \pm 1,41$ & $22,25 \pm 1,13$ & \\
\hline
\end{tabular}

Although physical activity is significant in a person's life and has an enormous influence on one's health and well-being, a growing number of students do not spend enough time doing exercise even if they participate in health science courses.

In our research, only $8 \%$ of the Italian women and $4 \%$ of the German women claimed that they were engaged in regular physical activity (at least 5 times a week as evidenced by Eurobarometer 72.3). Moreover, a total of $36 \%$ of the Italian and $52 \%$ of the German females admitted to doing exercise 1 to 4 times a week (with some regularity). What is worrying was that $56 \%$ of the Italian girls and $44 \%$ of German the girls were seldom physically active (1 to 3 times a month or less).

The German male population also seemed to be more active than the Italian one. A total of $44 \%$ of the German males claimed to be doing some exercise but seldom, while in the Italian population this value was higher (66\%). A total of $30 \%$ of the Italian and $54 \%$ of the German males did sports with some regularity. Only $2 \%$ of the Italian males were engaged in physical activity at least 5 times a week or did not know how much time they spent doing it. Only $2 \%$ of the German men were involved in doing regular physical activity. We did not notice any statistically significant differences between the countries and genders.

The next tested aspect was the places where sports were done, which could vary among students who came from different countries. In our research, the most often chosen place for females from both countries was a fitness centre. However, $64 \%$ of the German females and only $30 \%$ of the Italian females chose the same place. It turned out that it was quite common for the Italian female students to do exercise outside (26\%), which could be connected with good weather conditions throughout the year when compared to the ones in Germany. Instead, the German female students (24\%) did their physical activity at the university. The situation was also similar in the male population. The Italian male students tended to do exercise at a fitness centre (52\%) or in natural surroundings (30\%), whereas their German colleagues would rather choose a fitness centre (40\%) or played sports at the university (30\%). The values between the countries were found to be statistically significant $(p=0.000398)$, but the difference between genders was statistically insignificant. Figure 1 shows the percentage distribution of places where the students were engaged in physical activity. 


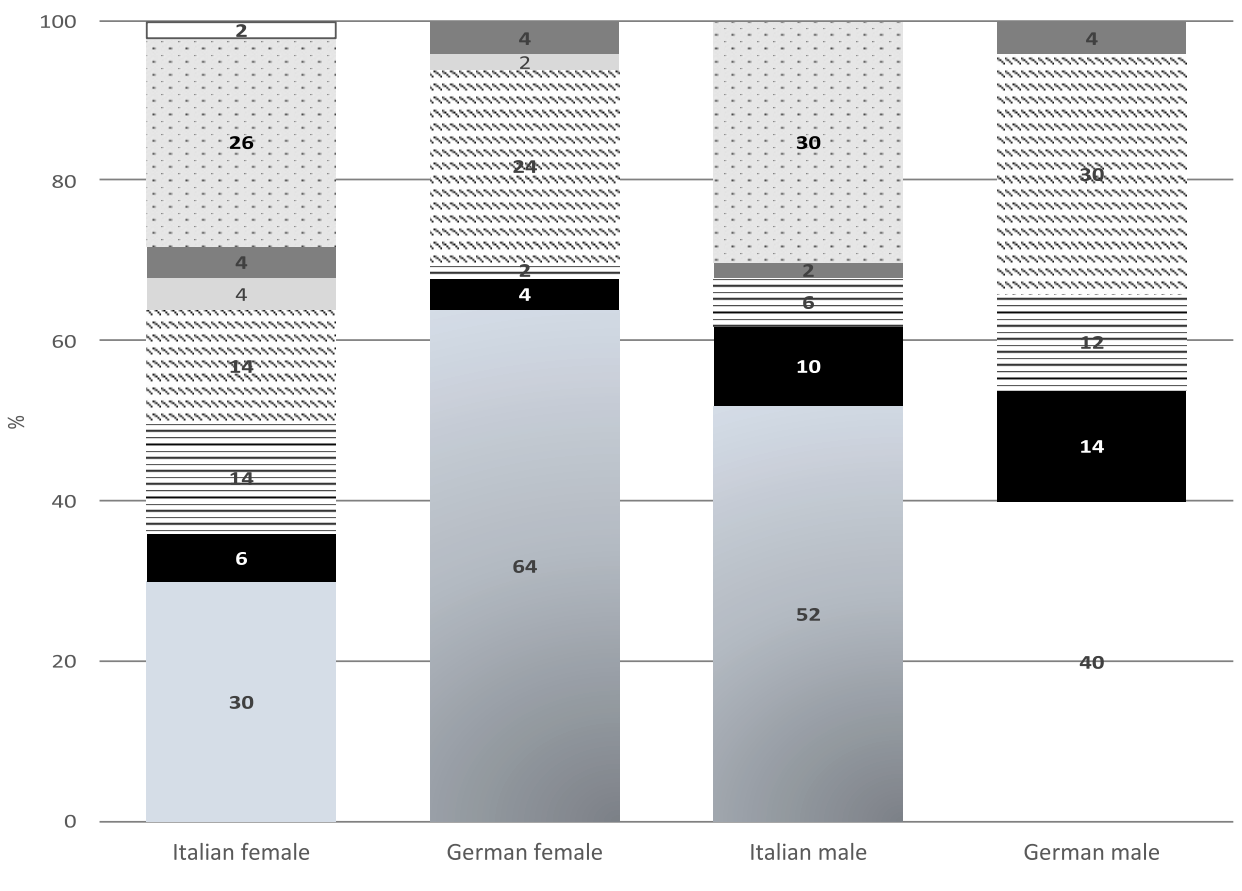

$\square$ fitness centre $\square$ sport club $=$ sport centre $\cdots$ university $\square$ work $\square$ on the way $:$ nature/park $\square$ elsewhere

Figure 1. Places of doing sports or physical activity by tested groups

The next investigated factor in the analysis concerned reasons why students avoided doing physical activity. For the Italian females, the most common one was their dislike of competition (40\%) and lack of time (26\%). Some (26\%) did not know what factor made them give up doing physical activity. In turn, the German females primarily pointed to not having enough time for physical activity (72\%) and the lack of a companion with whom they could exercise (14\%). In the male population, the situation was slightly different, as $84 \%$ of the German males and $46 \%$ of the Italian males stated that a lack of time was the most common cause which influenced their decreased physical activity. Besides, a quite relevant reason for the German males was the lack of a friend with whom they could practise sports together (10\%), whereas as many as $40 \%$ of the Italian males did not know what prevented them from doing physical activity. We observed statistically significant differences between countries $(p=0.000009)$; however, there were no values that were statistically significant between the sexes. The data are presented in Figure 2.

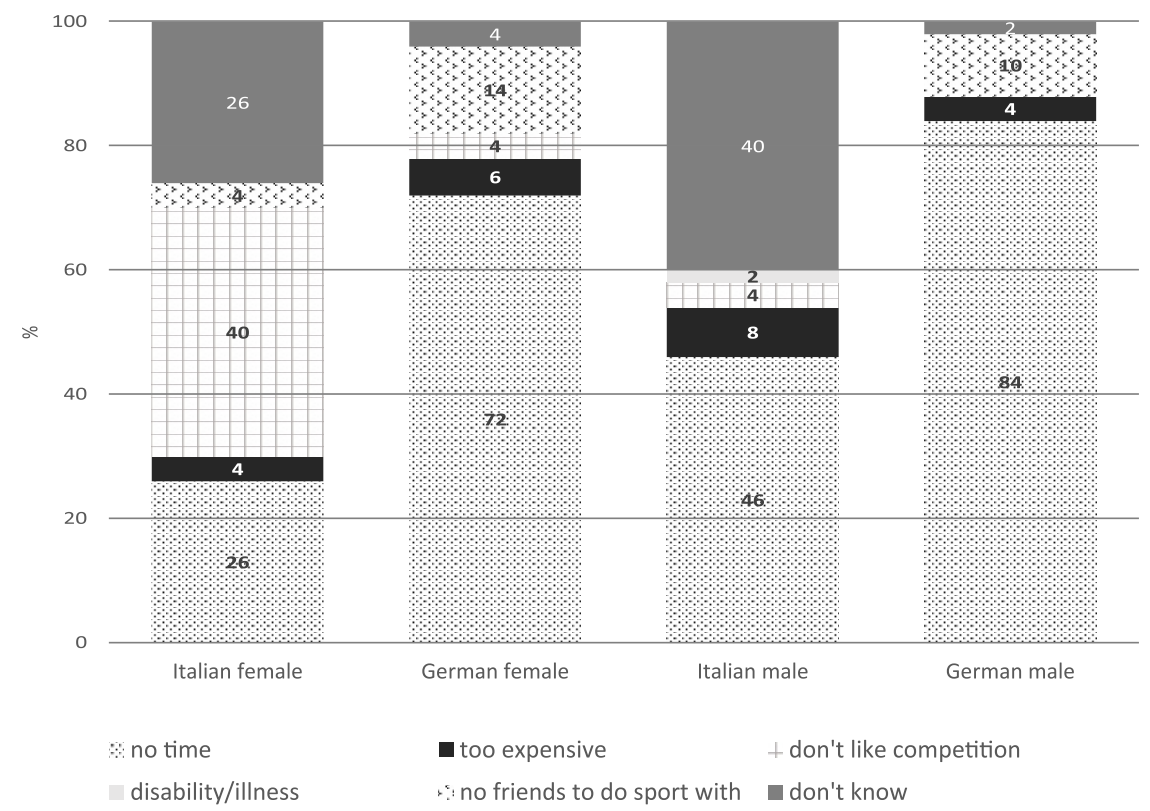

Figure 2. Factors contributing to physical inactivity 
The students were also asked whether they were interested in sports or not. As many as $32 \%$ of the Italian females and $8 \%$ of the German females definitely preferred or preferred spending their free time in different ways. On the other hand, $16 \%$ of the Italian females and $40 \%$ of the German females strongly indicated that sports were their hobby. In the male population, the differences were even more visible and the German males seemed more keen on sports than the Italian males. A total of $32 \%$ of the Italian males admitted that sports were or definitely were not their hobby, whereas only $20 \%$ of the Italian males strongly disagreed with the statement that they were not interested in sports. On the other hand, $46 \%$ of the German males tended to disagree and $54 \%$ strongly disagreed with that statement. The value was statistically significant between the two countries $(\mathrm{p}=0.000018)$ but there was no difference between the genders. The data are presented in Figure 3.

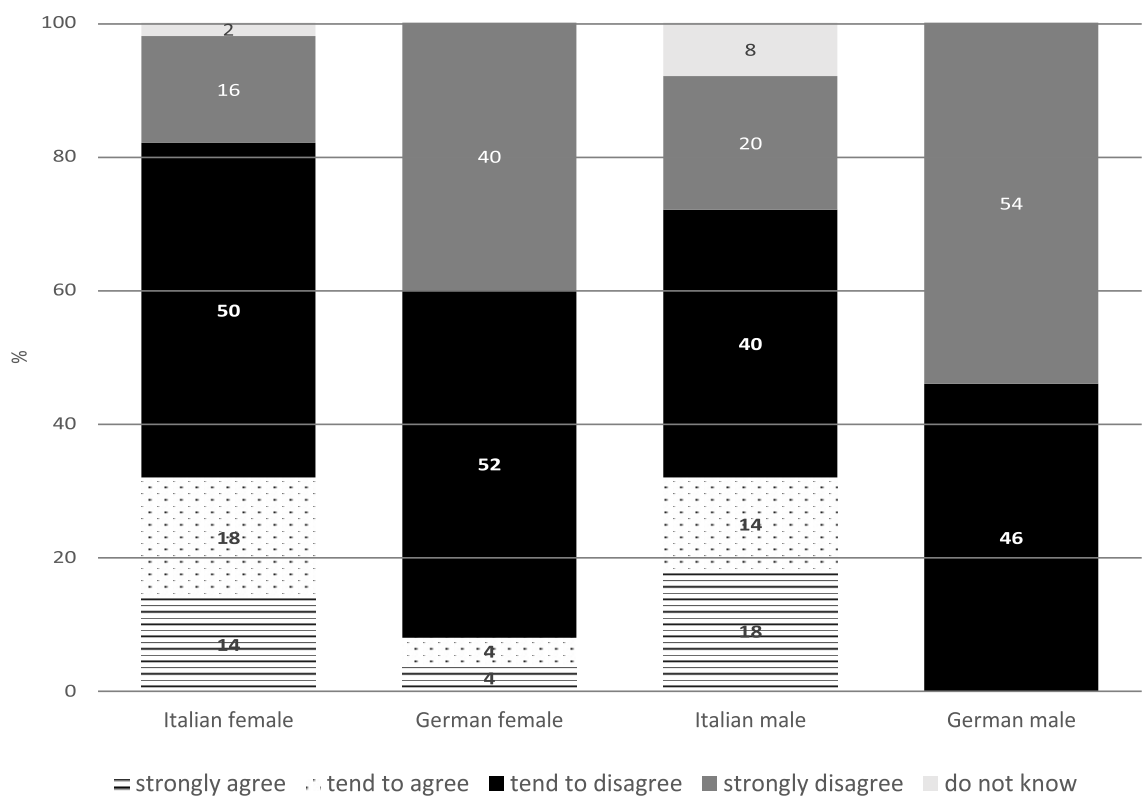

Figure 3. Students' opinion about not being interested in sport

\section{Discussion}

\section{Frequency of being involved in physical activity}

It is known that physical activity is very beneficial for individuals with regard to health as it reduces risk of heart disorders, strokes, type II diabetes or colon and breast cancer. If regularly done, it also improves peoples' psychological well-being. A physically active society means many savings in healthcare, whereas inactivity leads to certain diseases and is extremely costly. Although these facts seem to be obvious, it is common that medical students and doctors in the world are not as physically active as they should be $[2,5,12]$.

Voltmer et al. [2] researched the situation among 414 German physicians working in different private practices in Schleswig-Holstein. They noticed that the physicians were more physically active than others in the German society but that there was still room for improvement. In the examined group, there were $9.5 \%$ of inactive male doctors and $13.8 \%$ of inactive female physicians. On the other hand, there were $14 \%$ males and $15.6 \%$ females who practised sports more than 4 hours per week.

A similar issue referring to approximately 1600 Italian cardiologists was investigated by Temporelli et al. [17]. A very low level of physical activity or none was observed in $39.4 \%$ of the doctors, while intensive physical activity was seen in $15.1 \%$ of the individuals.

The situation in other countries also proves that medical students and doctors are often not as physically active as they should be. In a Polish research study prepared by Dąbrowska-Galas et al., [18], 45 medical students were surveyed and their results were then compared with students from other faculties of the Medical University. As many as $26 \%$ of the future doctors presented a low level of physical activity, while only $22 \%$ were physically active, and this activity could be characterised as high. Another Polish research done by Stasiołek and Jegier [19] also showed that medical students of the University of Łódź were not as physically active as they should be. They did not follow the WHO guidelines and recommendation on the level of physical activity.

On the other hand, over 600 medical students from other regions (Mediterranean, Scandinavia, Israel, Iran, Hungary) were surveyed by Terebessy et al. [6]. They noticed that Scandinavian medical students were the most active, while the participants from the Mediterranean region and Iran were the least. 
In our study, the results did not differ much. Although $8 \%$ of the Italian female students reported high physical activity (at least 5 times a week according to Eurobarometer 72.3), more than half seldom exercised ( 1 to 3 times per month or less) and only 36\% played sports quite regularly (1 to 4 times a week). The German females seemed to be more physically active; more than half practised sports with some regularity, $4 \%$ were highly physically active and another $44 \%$ rarely did any physical activity. Despite the fact that only $2 \%$ of Italian and German males reported high physical activity, as many as $66 \%$ of the Italian males and $44 \%$ of the German males were seldom involved in physical activity. A total of 30\% of the Italian males and $54 \%$ of the German males exercised with some regularity. Although most researchers noticed that medical students or doctors are not as physically active as they should be, Kozak et al. [20] found out in their research conducted on 646 students from the Medical University of Ternopil, Ukraine, that the participants demonstrated a high level of physical activity.

It is also common that men are more active than women; however, the opposite trend was observed in the Italian students. Whereas German males and females demonstrated a similar level of physical activity, it is noticeable that the Germans were more physically active than the Italians. The reason for this might be caused by the better socioeconomic background of the Germans, as it is known that less affluent people are less active due to a lack of time and poor access to sports leisure facilities [12].

Body mass index

In the following study, most of the students from both countries showed a normal BMI value. There was no positive correlation between a high frequency of practising sports and normal BMI, whereas only $4 \%$ of all students demonstrated high physical activity.

In their research on German doctors, Voltmer et al. [2] noticed that, although there were 58\% of physicians of both sexes with a normal BMI value, only $14.7 \%$ exercised more than 4 hours per week. In Italy, the situation was similar, as more than half of the cardiologists surveyed by Temporelli et al. [17] showed a normal BMI but high physical activity was observed in only 15.1\% of individuals. Moreover, Dąbrowska-Galas et al. [18] also confirmed this kind of relationship in medical students from Poland. Despite the fact that the BMI median value of the future physicians was 21.55 , only $22 \%$ demonstrated a high physical activity index.

\section{Places where sports are done}

The places where sports are done may differ among societies. This might be caused by different factors, such as socioeconomic status, the availability of sports facilities or patterns in doing certain sports resulting from parental upbringing $[12,15,21]$.

In the original Eurobarometer 72.3, the results are presented in relation to the whole society aged 15 and over, which do not divide people according to profession, show that there were no significant differences between both nations. As many as $60 \%$ of Germans and $40 \%$ of Italians practised sports outside, whereas $21 \%$ of Germans and $27 \%$ of Italians did physical activity on the way between home and school or work [16,22,23].

In our research, the situation was slightly different since we focused on young, future doctors. For the Italian students, it was most common to do sports at a fitness centre and outside. Doing sports in a park seems obvious due to the good weather conditions in Italy throughout the year in comparison to Germany. On the other hand, Germans usually practised sports at a fitness centre or at the university.

Similar situations were presented among medical students from Argentina in a publication by Bassan et al. [24]. They also noticed that future doctors usually were more active outside (running or walking) or at a gym. It was also shown that medical students from different regions of the world usually spent time being physically active outside, especially in the countries with many sunny days as they did not have much savings or used different sports facilities, usually a fitness centre.

\section{Factors causing physical inactivity}

A busy schedule and long and demanding courses of study may cause a limited physical activity in medical students. In their research on future physicians from Egypt and Saudi Arabia, El-Gilany et al. [5] noticed that the most common factors reducing the time of practising sports included: time limitations, lack of interest in physical activity and other priorities. For more than half of those surveyed, a limited access to sports facilities or no friend who could encourage them to do sports were important factors as well.

In a survey prepared by Khan et al. [25] on doctors and physiotherapists from Pakistan, the main factors which prevented them from doing physical activity were a lack of time and being tired. For many, doing physical fitness was too exhausting and having no company to do sports with was also relevant.

The results from American research presented by Akiyode et al. [26] on pharmacy students did not differ much. They observed that not enough time, lack of motivation and being tired were the most common factors that decreased students' physical activity.

In our research the results were similar. For the German students, the most common factor was a lack of 
time, but having a friend with whom they could practise sports together was also relevant. However, the Italian students pointed not only to a lack of time but also to the fact that they were not keen on competition, or they did not know which factors decreased their level of doing physical activity.

\section{Lack of interest in sports}

Physical activity is very crucial in medical students' life. As mentioned earlier, doctors who lead a healthy lifestyle much more often raise the topics related to it with their patients [5]. However, many medical students are not interested in sports, even though it is an essential point of discussion when counselling patients as well as taking care of their health.

Bassan et al. [24] noticed that, on a daily basis, Argentinean medical students more often chose social and cultural activities than practising sports. In the research study of El-Giany et al. [5], it was also visible that quite many future physicians from Egypt and Saudi Arabia were not interested in sports. In the survey on Polish medicine students, Dąbrowska-Galas et al. [18] observed that physical activity was an important part in their everyday lives (82\% of the participants), but only $68 \%$ confirmed the necessity of doing regular exercise regularly.

In our research this problem was also noticed. However, the German students seemed much more interested in sports than the Italians. Some Italian students strongly agreed or tended to agree that sports were not their hobby. These results were agreeable with those delivered by Eurobarometer 72.3 . Even $53 \%$ of the Italian and $34 \%$ of the German students 'strongly' or 'quite agreed' that they were not interested in sports. This may prove that German students were generally more physically active and were more keen on doing sports than the Italians $[16,22,23]$.

\section{Conclusions}

To sum up, it is common knowledge that physical activity is essential to humans. Although medical students are aware of the consequences of inactivity, they do not practise sports as much as they should. The German students were more physically active than the Italians; however, students of both nationalities did not see any need for improvement as far as sports are concerned. Our results are agreeable with research studies on a similar topic in other countries. It is also noticeable that the problem is enormous.

Medical students need more physical education during their studies. In the medical curriculum, there should be more emphasis on the benefits of physical activity with regard to patient counselling and taking care of one's own health. Students ought to be more encouraged to do sports, especially in the less economically sound countries. The idea of free access to the grounds at the university where the students can spend their free time seems to be one solution. We hope that our study will encourage other professionals to continue researching the physical activity in doctors and medical students in Europe.

\section{References:}

1. Stephens MB, Cochran C, Hall JM, Olsen C. Physical fitness during medical school: A 4-year study at the Uniformed Services University. Fam. Med. 2012; 44(10): 694-697.

2. Voltmer E, Frank E, Spahn C. Personal health practices and patient counselling of German physicians in private practice. ISRN Epidemiology 2013. doi: http://dx.doi.org/10.5402/2013/176020.

3. Cecil J, McHale C, Hart J, Laidlaw A. Behaviour and burnout in medical students. Med Educ Online 2014; 19: 25209. doi: http://dx.doi.org/10.3402/meo.v19.25209.

4. Kötter T, Tautphäus Y, Scherer M, Voltmer E.: Health-promoting factors in medical students and students of science, technology, engineering, and mathematics: design and baseline results of a comparative longitudinal study. BMC Med. Educ 2014; 14: 134. doi: 10.1186/1472-6920-14-134.

5. El-Gilany A-H, El-Masry R. Physical inactivity among Egyptian and Saudi medical students. TAF Prev. Med. Bull. 2011; 10(1): 35-44.

6. Terebessy A, Czeglédi E, Balla BC, Horváth F, Balázs P. Medical students' health behaviour and self-reported mental health status by their country origin: a cross-sectional study. BMC Psychiatry 2016; 16: 171. doi: 10.1186/s12888-016-0884-8.

7. Paro HBMS, Morales NMO, Silva CHM, Rezende CHA, Pinto RMC, Morales RR, et al. Health-related quality of life of medical students. Med Educ 2010; 44: 227-235.

8. Stoutenberg M, Stasi S, Stamatakis E, Danek D, Dufour T, Trilk JL, et al. Physical activity training in US medical schools: Preparing future physicians to engage in primary prevention. Phys. Sportsmed 2015; 43(4): 388-394. 
9. Bagordo F, Grassi T, Serio F, Idolo A, De Donno A. Dietary habits and health among university students living at or away from home in southern Italy. J. Food Nutr Res. 2013; 52(3): 164-171.

10. Majeed F. Association of BMI with diet and physical activity of female medical students at University of Dammam, Kingdom of Saudi Arabia. Journal of Taibah University Medical Sciences 2015; 10(2): 188-196.

11. Yılmaz Y, Vural E, Toprak DE, Gürdeniz E, Dede E, Oba MC, et al. The relationship between medical education and eating habits along with mental condition in medical students. Erciyes Med J 2014; 36(2): 75-81.

12. The economic cost of physical inactivity in Europe. An ISCA/ Cebr Report, [Internet] 2015 June, [cited 2016 Oct 12]. Available from: http://www.friendsofeurope.org/media/uploads/2015/06/The-Economic-Costsof-Physical-Inactivity-in-Europe-June-2015.pdf

13. Global recommendation on physical activity for health, WHO [Internet] 2010, [cited 2016 Oct 12]. Available from: http://apps.who.int/iris/bitstream/10665/44399/1/9789241599979_eng.pdf

14. Ortega FB, Ruiz JR, Labayen I, Martínez-Gómez D, Vicente-Rodriguez G, Cuenca-Garciá M, et al. Health inequalities in urban adolescents: Role of physical activity, diet and genetics. Pediatrics 2014; 133, e884, DOI: $10.1542 /$ peds.2013-1665

15. Reimers AK, Wagner M, Alvanides S, Steinmayr A, Reiner M, Schmidt S et al.: Proximity to sports facilities and sport participation for adolescents in Germany. PLoS One 2014; 9 (3): e93059, DOI:10.1371/journal. pone.0093059

16. Sport and Physical activity, Special Eurobarometer, Eurobarometer 72.3., [Internet] 2010 March, [cited 2016 Oct 13]. Available from: http://ec.europa.eu/public_opinion/archives/ebs/ebs_334_en.pdf

17. Temporelli PL, Zito G, Faggiano P, on behalf of the SOCRATES Investigators: Cardiovascular risk profile and lifestyle habits in a Cohort of Italian cardiologists (from the SOCRATES Survey). Am J Cardiol 2013; 112: 226-230.

18. Dąbrowska-Galas M, Plinta R, Dąbrowska J, Skrzypulec-Plinta V. Physical activity in students of the Medical University of Silesia in Poland. Phys Ther 2013; 93: 384-392.

19. Stasiołek D, Jegier A. Physical activity in medical students. Medical News 2003; 2(72): 140-142.

20. Kozak D, Korda M, Bergier J. Place of origin and place of residence versus level of physical activity of students of the Medical University in Ternopil, Ukraine. Health Problems of Civilization 2016; 10(4): 26-30.

21. McMinn AM. Griffin SJ, Jones AP, van Sluijs EMF: Family and home influences on children's after-school and weekend physical activity. Eur J Public Health 2013; 23 (5): 805-810.

22. Sport and Physical activity, Eurobarometer 72.3, Results for Italy, [Internet] 2010 [cited 2016 Oct 13]. Available from: http://ec.europa.eu/public_opinion/archives/ebs/ebs_334_fact_it_en.pdf

23. Sport and Physical activity, Eurobarometer 72.3, Results for Germany, [Internet] 2010 [cited 2016 Oct 13 ]. Available from:http://ec.europa.eu/public_opinion/archives/ebs/ebs_334_fact_de_en.pdf

24. Bassan ND, D’Ottavio AE, Vinuesa MA, Soldano OF, Mónaco MC, Robotti M et al: Availability and use of leisure time in students of an Argentinean Medical School: a contribution pursuing wellbeing. ER 2012; 3(5): 468472 .

25. Khan DA, Zaidi R, Danish SH, Ahmad F, Sarfraz M: Attitude towards physical activity: A comparative study among doctors and physical therapists. J Dow Health Sci 2013; 7(2): 68-72.

26. Akiyode O, Nguyen A, Augusto J, Wiley K, Ettienne E. Adopting physical activity lifestyle in a pharmacy curriculum. Pharmacy Education 2015; 15(1): 14-16. 